\title{
SCIENCE AND ENGINEERING
}

\author{
OF
}

\section{COMPOSITE MATERIALS}

VOLUME 5, NO. 1

TABLE OF CONTENTS

Effects of Stress Ratio on the Flexural Fatigue Behavior of Continuous Strand Mat Reinforced Plastics

by A. D'Amore, G. Caprino, P. Stupak, J. Zhou and L. Nicolais 1

Effects of Alloying Elements on Interface and Properties of $\mathrm{C} / \mathrm{Cu}$ Composites

by X. Kuang, G. Carotenuto, Z. Zhu and L. Nicolais...

Thermodynamic Investigation of the Aluminum Carbide Formation in Al-SiC Composite by Image Analysis

by $\mathrm{G}$. Carotenuto, L. Nicolais and X. Kuang

Design of a High Pressure Rig for Biaxial and Triaxial Compression

Testing of Composite Tubes

by A.S. Kaddour and P.D. Soden

Free and Bond Water Type Models of Penetrant Sorption in Epoxies by P.J. Shopov, P. Frolkovic and W.P. De Wilde.

Copyright $(1996$

FREUND PUBLISHING HOUSE, LTD

Suite 500, Chesham House

150 Regent Street

London WIR 5FA

England 